\title{
Erzurum İli Merkez İlçelerinin Su Ürünleri Tüketim Davranışları Üzerine Araştırmalar
}

\author{
Yaşar KARAKULAK ${ }^{1}{ }^{\mathbb{D}}$, Gökhan ARSLAN ${ }^{2 *} \mathbb{D}$, Telat YANIK $^{3} \mathbb{C}$ \\ ${ }^{1}$ Atatürk Üniversitesi, Fen Bilimleri Enstitüsü, Erzurum, Türkiye \\ ${ }^{2}$ Atatürk Üniversitesi, Su Ürünleri Fakültesi, İşleme Teknolojisi Anabilim Dalı Erzurum, Türkiye \\ ${ }^{3}$ Atatürk Üniversitesi, Su Ürünleri Fakültesi, Yetiştiricilik Anabilim Dalı, Erzurum, Türkiye
}

*Sorumlu Yazar: gokhan.arslan@atauni.edu.tr

Araştırma Makalesi

Geliş 02 Ocak 2020; Kabul 28 Nisan 2020; Basım 01 Haziran 2020.

Alıntılama: Karakulak, Y., Arslan, G., \& Yanık, T. (2020). Erzurum ili merkez ilçelerinin su ürünleri tüketim davranışları üzerine araştırmalar. Acta Aquatica Turcica, 16(2), 290-300. https://doi.org/10.22392/actaquatr.669336

\section{Özet}

Su ürünleri zengin mineral, protein ve yağ içeriklerinden dolayı insan beslenmesinde önerilen gıdalar arasında yer almaktadır. Bazı su ürünleri, yüksek yağ içeriklerinden dolayı depolamaktan ziyade taze olarak tüketilmektedirler. Hem tedarik edilmesi hem yeme alışkanlıkları hem de muhafazasında görülen güçlükler maalesef ülkemizde bu ürünlerin yeterince tüketilememesine sebep olmaktadır. Mevcut araştırma, Erzurum ili merkez ilçelerinde, tüketim seviyesinin tespit edilmesi, alınması gereken muhtemel teşvik edici önlemlerin belirlenmesi, su ürünleri tüketim miktarları ve şekillerini tespit etmek amacıyla, yüz yüze görüşme anket tekniği kullanılarak 30 Nisan-30 Mayıs 2019 tarihleri arasında yapılmıştır. Araştırmada, katılımcılara su ürünleri tüketim miktarları ve alışkanlıkları ile ilgili çeşitli sorular yöneltilerek, katılımcıların sosyodemografik özellikleri ile tüketim alışkanlıkları arasındaki ilişkiler incelenmiştir Çalışmada; "Ana kitle oranlarına dayalı kümelendirilmemiş tek aşamalı basit tesadüfî olasılık örneklemesi" yöntemi kullanılarak, \%38'ini bayanların oluşturduğu toplam 677 kişi ile yüz yüze anket yapılmıştır. Anket çalışmasına katılan tüketicilerin \%45,8'ini genç yaş grubunun oluşturduğu, \%92,8'sinin balık tüketmemiz gerektiğini düşündüğü, \%64,4'ünün Erzurum'da balık fiyatlarını pahalı bulduğu, $\% 46,7$ 'sinin balık satın alırken taze olup olmadığına dikkat ettiği, \%55,1'inin en fazla hamsi balığını tükettiği, \%54,7'sinin ise aylık balık tüketim ortalamasının 0-3 kg olduğu anket çalışması sonucunda ortaya çıkmıştır.

Anahtar Kelimeler: Erzurum, su ürünleri tüketimi, tüketici tercihleri.

Researches On Fishery Consumption Behaviors of Erzurum Central Districts

\begin{abstract}
As an important food source that contributes to the development and protection of health in every period of life, seafood is recommended to consume regularly because it contains nutrients such as good quality protein and long-chain polyunsaturated n-3 fatty acids. In the central districts of Erzurum, surveys were conducted to investigate how this valuable nutrient is consumed by using face to face interview techniques from 30 April to 30 May of 2019. Various questions about consumption habits were asked to the participants and the relationship between socio-demographic characteristics and consumption habits was examined. According to the findings obtained in the face-to-face surveys with 677 consumers by using ' based on population rates non-clustered single-stage simple random probability sampling" method; it was determined that $38 \%$ of the consumers were female and $62 \%$ were male. Survey results revealed that from the participants; $45.8 \%$ of them are young age group, $92.8 \%$ think that we should consume fish, $64.4 \%$ found that fish prices in Erzurum are expensive, $46.7 \%$ paid attention to whether they are fresh or not when buying fish, $55.1 \%$ consume mostly anchovy and the average monthly fish consumption of $54.7 \%$ of the participants is at $0-3 \mathrm{~kg}$.
\end{abstract}

Keywords: Erzurum, seafood consumption, consumer preferences

\section{GíRiş}

Beslenme ve gida yetersizliğinin hızla artan dünya nüfusunun gelecekte karşılaşacağı en önemli sorunlar arasında yer alacağı düşünülmektedir. Uzmanlar 2050’li yıllarda artan dünya nüfusu paralel olarak mevcut gıda üretiminin iki katına çıkartılması gerekliliğini vurgulamaktadırlar su Ürünleri yetiştiriciliği bu ihtiyacın karşılanabilmesi için önemli bir potansiyele sahiptir (Arslan, 2019). Bu anlamda su ürünleri üretiminin dünyada giderek artan protein ihtiyacını karşılamak için, gelecek 50 yıldaki en büyük gıda kaynaklarından birisi olacağı bildirilmektedir (FAO, 2012). Tüketim bakımından su ürünleri; yumuşakçalar, kabuklular ve ekinodermler gibi kabuklu deniz ürünleri ile her 
çeşit balık ve deniz memelilerini içermektedir. Dünyada ki tüm bölgelerde birçok balık türü yiyecek olarak tüketilmektedir (Baysal, 2004). Balık etinde bağ dokusu (\%3) kırmızı ete kıyasla (\%15) oldukça düşük olduğundan, erken pişmesi ve parçalanması kolay olduğundan çiğneme sorunu gibi çeşitli sağlık sorunlarına sahip olan kişilerce tercih edilmektedir (Brown, 2000). Balık etinin bazı hastalıkların önlenmesinde önemli derecede etkili olduğu bildirilmektedir (Maskan, 2005; Erkan, 2013; Gorga, 1998). Balık yağında bulunan omega-3 yağ asitlerinin meme, kalın barsak ve prostat kanserlerinde tümör gelişimini engelleyici etkileri rapor edilmiştir (Pigott ve Tucker, 1990). Baysal (2004), Et ile beslenenlere kıyasla, balıkla beslenen kişilerde kalp rahatsızlıklarının daha az görüldüğünü bildirmektedir. Somon balığı ile beslenen bireylerde kanda kolesterol ve trigliserid seviyelerinin düştüğü tespit edilmiştir (Turan vd., 2006). Dolayısıyla, su ürünleri sağlık bakımından oldukça önemli olup, sağlıklı bir yaşam için düzenli olarak tüketilmelidir.

Dünya geneli ve Avrupa Birliği ülkeleri özelinde kıyaslandığında, ülkemizde kişi başına düşen su ürünleri tüketimi oldukça düşüktür. Toplumlarda artan eğitim seviyesi ile bilinçli gıda tüketimi arasında pozitif bir ilişkinin olduğu bildirilmektedir (Karabulut ve Yand1, 2006). Ülkemizde akuakültür ile üretim miktarı yıldan yıla artmaktadır. Akuakültürde alabalık, çipura ve levrek ilk sıralarda yer almaktadır. Avcılık bakımından ele alındığında ise, miktarları yıldan yıla dalgalanma göstermekle birlikte denizlerimizde hamsi, sardalya, istavrit, palamut-torik, çaça balığı, mezgit, istavrit (karagöz) ve lüfer toplam av miktarının yaklaşık \%90'ını oluşturmaktadır. Diğer deniz ürünleri ise kalan kısmı oluşturmaktadır. En fazla avcılığı yapılan tür beyaz kum midyesi olarak rapor edilmiştir (TUiK, 2014). Doğu Anadolu' nun en eski yerleşim birimlerinden birisi olan Erzurum, oldukça zengin su kaynaklarına, çevresiyle güçlü ekonomik ve sosyal ilişkilere sahip olmasına rağmen, maalesef çeşitli sosyal ve ekonomik faktörlerden dolayı Erzurum ilinde yapılan balıkçılık faaliyetlerinin ve tüketilen balık miktarının mevcut potansiyelin altında olduğu rapor edilmiştir (Hisar vd., 2002). Bu durumun nedenleri gelecek açısından son derece önemlidir. Mevcut yetiştiricilik potansiyelinin fazla olmasına rağmen, işletme sayısının azlığı ve balık tüketim miktarının düşük seviyelerde bulunmasının sebepleri önemlidir.

Bu çalışmamızda Erzurum'un merkez ilçeleri Yakutiye, Palandöken ve Aziziye'de ikamet eden 677 kişi konu edilmiştir. Anket formları verilerin homojenliği bakımından ilçelerde farklı mahallelerde uygulanmıştır. Elde edilecek verilerin güvenilirliğinin arttırılması bakımından; farklı gelir seviyeleri olan, farklı sosyal imkanlara sahip ve farklı meslek gruplarında çalışan kişilere anket formlarının uygulanmasına özen gösterilmiştir.

\section{MATERYAL ve YÖNTEM}

Çalışmamız Erzurum İli’’ndeki 20 ilçenin nüfus yoğunluğu ve diğer ilçelerle ilişkileri düşünülerek en yoğun üç merkez ilçesi olan, nüfus yoğunluğuna göre Yakutiye, Palandöken ve Aziziye ilçelerinde yapılmıştır. Örnekleme sahası olarak; çalışma yapıldığ 1 dönem ki, 191224 nüfuslu Yakutiye, 168651 nüfuslu Palandöken ve 62289 kişi nüfusa sahip Aziziye ilçeleri seçilmiştir. Araştırmada üç ilçede ikamet eden kişilere 30 Nisan - 30 Mayıs 2019 tarihleri arasında anket formları yöneltilerek onların su ürünleri tüketim alışkanlıkları tespit edilmiştir.

Erzurum ili merkez ilçelerinde tesadüfi olarak seçilen 677 kişiyle yüz yüze görüşme yapılarak elde edilen araştırma verileri istatistiki analizlere tabi tutulmuştur. "Chi-Square Tests" sürekli bir dağılım olup genellikle iki bağımsız kategorik kriteri test etmek için kullanılır. Bu nedenle çalışmamızdan elde edilen veriler SPSS paket programı kullanılarak "Chi-Square Tests" sonuçları ile yorumlanmıştır.

\section{BULGULAR}

\section{Demografik Bilgilere İlişkin Bulgular}

Çalışmamıza katılan 677 kişinin \%38'ni (257) kadın \%62'sini (420) Erkek bireyler oluşturmaktadır.

Yaş grupları dört ana başlık altında toplanarak değerlendirilmiştir. Buna göre, 18 yaş altı Çocuk, 18-30 yaş aralı̆̆ına Genç, 31-50 yaş aralığına Yetişkin ve 51 yaş ile üzerine ise Yaşlı şeklinde ayırım yapılmaya gidilmiş̧ir. Ankete katılım sağlayan kişilerin yaş dağılımlarının su ürünleri tüketiminde ki etkileri incelenmiştir. Böylece çalışmamıza katılanların \%9,9 çocuk, \%45,8 genç, \%33,2 yetişkin ve $\% 11,1$ ise yaşlı grubunu temsil etmektedir.

İnsanların eğitim durumları ile kişisel tercihlerinin farklılık gösterdiğini ve bu bağlamda tüketicilerin bilinç düzeyi ve tüketimin doğrudan ilişkili olduğunu varsayarak katılımcılarımıza eğitim 
durumları sorulmuş; \%2,4 okur-yazar değil, \%5,8 okur-yazar, \%17,6 ilkokul-ortaokul, \%30,3 Lise, \%44 Üniversite ve üzeri tahsile sahip olduğu tespit edilmiştir. Böylece spesifik tüketim soruları ile eğitim durumları arasında bir anlam olup olmadığı çalışmamızda irdelenmiştir.

Meslek grupları ile tüketim arasındaki ilişkiyi incelemek amacıyla kişilere uğraştıkları meslekler sorulmuş alınan cevaplara göre; \%24,5 öğrenci, ev hanımı, emekli ve geçici işsizlerden oluşmaktadır, \%43,9 özel sektör dallarında çalıştığ 1 ve \%31,6 ise kamu sektöründe çalıştığını beyan etmiştir.

Bilindiği üzere kişiler harcamalarını gelir durumlarına göre yapmaktadırlar. Tüketiciler ekonomik yönden ne kadar özgürse bir o kadar da tüketim alanında özgürce hareket etmektedirler. Ankete katılan tüketiciler aylık gelir durumları yönünden incelenmiş alınan verilere göre; \%39 aylık $2000 \mathrm{TL}$ ve alt1, \%35,6 aylık 2001- 3500 TL, \%25,4 aylık 3501 TL ve üzeri gelire sahip olduğu ortaya çıkmış olup insanların su ürünleri satın alma potansiyelinin bu doğrultuda tutum ve davranışları genel olarak incelenerek çalışmamıza konu edilmiştir.

Çalışmamıza katılım sağlayan tüketicilerin hangi ilçelerde ikamet ettikleri belirlenmiştir. Böylece Erzurum'un merkez ilçeleri arasında tüketim alışkanlığı farklılıkları ve benzerliklerinin olup olmadığını araştırmaktır. Erzurum'un üç merkez ilçesi bulunmaktadır. Bunlar sırasıyla Yakutiye, Palandöken ve Aziziye'dir. Ankete katılanlar \%46,1'i Yakutiye, \%36,5'i Palandöken ve \%17,4'ü Aziziye de ikamet etmektedir. Bu oranlar ilçelerin nüfus yoğunluğu ile doğru orantılıdır. Demografik bilgilere ait bulgular Tablo 1'de verilmiştir.

Tablo 1. Demografik bilgilere ait bulgular

\begin{tabular}{cc}
\hline \hline Cinsiyet & $\%$ \\
\hline Bayan & 38 \\
Bay & 62 \\
\hline Yaş & $\%$ \\
\hline 18 Çocuk Genç & 9,9 \\
$31-50 \quad$ Yetişkin & 45,8 \\
$51>\quad$ Yaşlı & 33,2 \\
\hline Eğitim Durumları & 11,1 \\
\hline Okur-yazar değil & $\%$ \\
Okur-yazar & 2,4 \\
Illkokul-Ortaokul & 5,8 \\
Lise & 17,6 \\
Üniversite ve üzeri & 30,2 \\
\hline Meslek Grupları & 44 \\
\hline Özel sektör çalışanı & $\%$ \\
Kamu çalışanı & 24,5 \\
\hline Gelir Düzeyleri & 43,9 \\
\hline 2000 TL < & 31,6 \\
\hline 2001-3500 TL & $\%$ \\
3501 TL > & 39 \\
İkamet Durumları & 35,6 \\
\hline Yakutiye & 25,4 \\
\hline Palandöken & $\%$ \\
Aziziye & 46,1 \\
\hline
\end{tabular}

\section{Tüketim İle Alakalı Bulgular}

Cinsiyete bağlı olarak "Balık satın alırken en çok nelere dikkat edersiniz" sorusuna katılımcıların vermiş oldukları cevapların Ki-Kare testi ile analizi Tablo 2'de verilmiştir. 
Tablo 2. Balık satın alırken en çok nelere dikkat edersiniz?

\begin{tabular}{clllllll}
\hline \hline & Fiyatına & $\begin{array}{c}\text { Lezzetli } \\
\text { Olmasına }\end{array}$ & Tazeliğine & $\begin{array}{c}\text { Az Kılçılı } \\
\text { Olmasına }\end{array}$ & Hepsi & Diğer & Toplam \\
\hline Kadın & 34 & 11 & 138 & 16 & 58 & 0 & 257 \\
$\%$ & 13,2 & 4,3 & 53,7 & 6,2 & 22,6 & 0,0 & 100,0 \\
Erkek & 70 & 25 & 178 & 25 & 107 & 15 & 420 \\
$\%$ & 16,7 & 6,0 & 42,4 & 6,0 & 25,5 & 3,6 & 100,0 \\
\hline Toplam & 104 & 36 & 316 & 41 & 165 & 15 & 677 \\
$\%$ & 15,4 & 5,3 & 46,7 & 6,1 & 24,4 & 2,2 & 100,0 \\
\hline \hline
\end{tabular}

Pearson Chi-Square: $16,190 \mathrm{p}<0.05$

Tablo 2'de verilen bilgiler doğrultusunda "Balık satın alırken en çok nelere dikkat edersiniz" sorusuna verilen cevaplar bakımından cinsiyetler arasında bir farklılığın olup olmadığını tespit etmek amacıyla yapılan Ki-Kare bağımsızlık testi sonucunda önemli bir farklılığın olduğu ortaya çıkmışır $(p<0,05)$. Kadınların \%53,7'si tazeliğine dikkat ederken, erkeklerde bu oran \%42,4 olarak belirlenmiştir.

Cinsiyete bağlı olarak "Balık Dışı En Çok Hangi Su Ürünlerini Tüketmektesiniz" sorusuna katılımcıların vermiş oldukları cevapların Ki-Kare testi ile analizi Tablo 3'de verilmiştir.

Tablo 3. Balık dışı en çok hangi su ürünlerini tüketmektesiniz?

\begin{tabular}{ccccccccccc}
\hline \hline & Midye & İstakoz & Kerevit & Salyangoz & Kalamar & Karides & Hepsi & Diğer & Hiçbiri & Toplam \\
\hline Kadın & 52 & 4 & 9 & 9 & 5 & 16 & 13 & 6 & 143 & 257 \\
$\%$ & 20,2 & 1,6 & 3,5 & 3,5 & 1,9 & 6,2 & 5,1 & 2,3 & 55,6 & 100,0 \\
Erkek & 154 & 7 & 15 & 12 & 15 & 27 & 20 & 29 & 141 & 420 \\
$\%$ & 36,7 & 1,7 & 3,6 & 2,9 & 3,6 & 6,4 & 4,8 & 6,9 & 33,6 & 100,0 \\
\hline Toplam & 206 & 11 & 24 & 21 & 20 & 43 & 33 & 35 & 284 & 677 \\
$\%$ & 30,4 & 1,6 & 3,5 & 3,1 & 3,0 & 6,4 & 4,9 & 5,2 & 41,9 & 100,0 \\
\hline \hline
\end{tabular}

Pearson Chi-Square: $40,799 \mathrm{p}<0.05$

Tablo 3'de verilen bilgiler doğrultusunda "Balık dışı en çok hangi su ürünlerini tüketmektesiniz" sorusuna verilen cevaplar bakımından cinsiyetler arasında bir farklılığın olup olmadığını tespit etmek amacıyla yapılan Ki-Kare bağımsızlık testi sonucunda önemli bir farklılığın olduğu ortaya çıkmıştır $(p<0,05)$. Kadınların \%55,6'sı balık dışında herhangi bir su ürünü tüketmezken, erkeklerde bu oran $\% 33,6$ olarak belirlenmiştir.

Yaş aralığına bağlı olarak "Balık tüketmenizin en önemli sebebi nedir" sorusuna katılımcıların vermiş oldukları cevapların Ki-Kare testi ile analizi Tablo 4'te verilmiştir.

Tablo 4. Balık tüketmenizin en önemli sebebi nedir?

\begin{tabular}{cccccc}
\hline \hline & $\begin{array}{c}\text { Lezzetli Olduğu } \\
\text { İçin }\end{array}$ & $\begin{array}{c}\text { Sağlıklı Olduğu } \\
\text { İçin }\end{array}$ & Hepsi & Diğer & Toplam \\
\hline Çocuk (18 yaş altı) & 7 & 54 & 2 & 4 & $67(\% 9,9)$ \\
$\%$ & 10,4 & 80,6 & 3,0 & 6,0 & 100,0 \\
Genç (18-30) & 45 & 111 & 38 & 116 & $310(\% 45,8)$ \\
$\%$ & 14,5 & 35,8 & 12,3 & 37,4 & 100,0 \\
Yetişkin (31-50) & 42 & 100 & 23 & 60 & $225(\% 33,2)$ \\
$\%$ & 18,7 & 44,4 & 10,2 & 26,7 & 100,0 \\
Yaşlı (50+) & 18 & 34 & 19 & 4 & $75(\% 11,1)$ \\
$\%$ & 24,0 & 45,3 & 25,3 & 5,3 & 100,0 \\
\hline Toplam & 112 & 299 & 82 & 184 & $677(\% 100)$ \\
$\%$ & 16,5 & 44,2 & 12,1 & 27,2 & 100,0 \\
\hline \hline
\end{tabular}

Pearson Chi-Square: $82,816 \mathrm{p}<0.05$

Tablo 4'de verilen bilgiler doğrultusunda "Balık tüketmenizin en önemli sebebi nedir?" sorusuna verilen cevaplar bakımından yaşlar arasında bir farklılığın olup olmadığını tespit etmek amacıyla yapılan Ki-Kare bağımsılılı testi sonucunda önemli bir farklılığın olduğu ortaya çıkmıştır $(p<0,05)$. Yaşları 18 altı olan çocukların \%80,6'sı balık tüketiminin sağlıklı olduğunu düşünürken, yaşları 18 ile 30 arasında olan gençlerde bu oran \%35,8 olarak belirlenmiştir. 
Yaş aralığına bağlı olarak "Sizce balık tüketimini etkileyen faktörlerden en önemlisi nedir" sorusuna katılımcıların vermiş oldukları cevapların Ki-Kare testi ile analizi Tablo 5'de verilmiştir.

Tablo 5. Sizce balık tüketimini etkileyen faktörlerden en önemlisi nedir?

\begin{tabular}{cccccccc}
\hline \hline & $\begin{array}{c}\text { Fiyatın } \\
\text { Pahalı } \\
\text { Olması }\end{array}$ & Kokusu & Tadı & $\begin{array}{c}\text { Reklam } \\
\text { Yetersizliği }\end{array}$ & Hepsi & Diğer & Toplam \\
\hline Çocuk (18 yaş altı) & 14 & 5 & 1 & 2 & 44 & 1 & 67 \\
$\%$ & 20,9 & 7,5 & 1,5 & 3,0 & 65,7 & 1,5 & 100,0 \\
Genç (18-30) & 161 & 31 & 13 & 22 & 69 & 14 & 310 \\
$\%$ & 51,9 & 10,0 & 4,2 & 7,1 & 22,3 & 4,5 & 100,0 \\
Yetişkin (31-50) & 127 & 29 & 15 & 5 & 43 & 6 & 225 \\
$\%$ & 56,4 & 12,9 & 6,7 & 2,2 & 19,1 & 2,7 & 100,0 \\
Yaşlı (50+) & 51 & 8 & 5 & 3 & 6 & 2 & 75 \\
$\%$ & 68,0 & 10,7 & 6,7 & 4,0 & 8,0 & 2,7 & 100,0 \\
\hline Toplam & 353 & 73 & 34 & 32 & 162 & 23 & 677 \\
$\%$ & 52,1 & 10,8 & 5,0 & 4,7 & 23,9 & 3,4 & 100,0 \\
\hline \hline
\end{tabular}

Tablo 5'de verilen bilgiler doğrultusunda "Sizce balık tüketimini etkileyen faktörlerden en önemlisi nedir" sorusuna verilen cevaplar bakımından yaşlar arasında bir farklılığın olup olmadığını tespit etmek amacıyla yapılan Ki-Kare bağımsızlık testi sonucunda önemli bir farklılığın olduğu ortaya çıkmıştır $(\mathrm{p}<0,05)$. Yaşları 18 altı olan çocukların \%65,7'si balık tüketimini etkileyen faktörlerden hepsi (fiyatının pahalı olması, kokusu, tadı ve reklam yetersizliği) cevabını verirken, yaşları 50 ve üzerinde olan yaşl1larda bu oran $\% 8,0$ olarak belirlenmiştir.

Eğitim durumuna göre "Su ürünleri denilince aklınıza gelen ilk canlı türü hangisidir" sorusuna katılımcıların vermiş oldukları cevapların Ki-Kare testi ile analizi Tablo 6’te verilmiştir.

Tablo 6. Su ürünleri denilince aklınıza gelen ilk canlı türü hangisidir?

\begin{tabular}{ccccccc}
\hline \hline & Balık & Yumuşakçalar & Kabuklular & Zooplanktonlar & Su & Toplam \\
\hline Okur Yazar Değil & 7 & 2 & 2 & 2 & 3 & $16(\% 2,4)$ \\
$\%$ & 43,8 & 12,5 & 12,5 & 12,5 & 18,8 & 100,0 \\
Okur Yazar & 29 & 0 & 5 & 4 & 1 & $39(\% 5,8)$ \\
$\%$ & 74,4 & 0,0 & 12,8 & 10,3 & 2,6 & 100,0 \\
İlkokul-Ortaokul & 98 & 7 & 12 & 0 & 2 & $119(\% 17,6)$ \\
$\%$ & 82,4 & 5,9 & 10,1 & 0,0 & 1,7 & 100,0 \\
Lise & 187 & 11 & 2 & 2 & 3 & $205(\% 30,3)$ \\
$\%$ & 91,2 & 5,4 & 1,0 & 1,0 & 1,5 & 100,0 \\
Üniversite ve Üzeri & 275 & 4 & 8 & 6 & 5 & $298(\% 44)$ \\
$\%$ & 92,3 & 1,3 & 2,7 & 2,0 & 1,7 & 100,0 \\
\hline Toplam & 596 & 24 & 29 & 14 & 14 & $677(\% 100)$ \\
$\%$ & 88,0 & 3,5 & 4,3 & 2,1 & 2,1 & 100,0 \\
\hline \hline Pearson Chi-Square: $90,986 \mathrm{p}<0.05$ & & & & &
\end{tabular}

Tablo 6'da verilen bilgiler doğrultusunda "Su ürünleri denilince aklınıza gelen ilk canlı türü hangisidir?" sorusuna verilen cevaplar bakımından eğitim durumları arasında bir farklılığın olup olmadığını tespit etmek amacıyla yapılan Ki-Kare bağımsızlık testi sonucunda önemli bir farklılığın olduğu ortaya çıkmıştır $(\mathrm{p}<0,05)$. Üniversite ve üzeri mezunlarının \%92,3'ünün aklına ilk gelen balık olurken, okuryazar olmayanlarda bu oran $\% 43,8$ olarak belirlenmiştir.

Eğitim duruma bağlı olarak "Sizce balık tüketmeli miyiz" sorusuna katılımcıların vermiş oldukları cevapların Ki-Kare testi ile analizi Tablo 7'de verilmiştir. 
Tablo 7. Sizce balık tüketmeli miyiz?

\begin{tabular}{cccc}
\hline \hline & Evet & Hayır & Toplam \\
\hline Okur Yazar Değil & 9 & 7 & 16 \\
$\%$ & 56,3 & 43,8 & 100,0 \\
Okur Yazar & 28 & 11 & 39 \\
$\%$ & 71,8 & 28,2 & 100,0 \\
İlkokul-Ortaokul & 114 & 5 & 119 \\
$\%$ & 95,8 & 4,2 & 100,0 \\
Lise & 187 & 18 & 205 \\
$\%$ & 91,2 & 8,8 & 100,0 \\
Üniversite Ve Üzeri & 290 & 8 & 298 \\
$\%$ & 97,3 & 2,7 & 100,0 \\
\hline Toplam & 628 & 49 & 677 \\
$\%$ & 92,8 & 7,2 & 100,0 \\
\hline \hline
\end{tabular}

Pearson Chi-Square: $68,870 \mathrm{p}<0.05$

Tablo 7'de verilen bilgiler doğrultusunda "Sizce balık tüketmeli miyiz?" sorusuna verilen cevaplar bakımından eğitim durumları arasında bir farklılığın olup olmadığını tespit etmek amacıyla yapılan Ki-Kare bağımsızlık testi sonucunda önemli bir farklılığın olduğu ortaya çıkmıştır $(p<0,05)$. Üniversite ve üzeri mezunlarının \%97,3'ü balık tüketilmesine evet cevabı verirken, okuryazar olmayanlarda bu oran \%56,3 olarak belirlenmiştir.

Gelir durumuna bağlı olarak "En fazla tükettiğiniz balık türü nedir" sorusuna katılımcıların vermiş oldukları cevapların Ki-Kare testi ile analizi Tablo 8'de verilmiştir.

Tablo 8. En fazla tükettiğiniz balık türü nedir?

\begin{tabular}{ccccccccc}
\hline \hline & Hamsi & İstavrit & Alabalık & Sazan & $\begin{array}{c}\text { Çipura } \\
\text { Levrek }\end{array}$ & Somon & $\begin{array}{c}\text { Diğer Balık } \\
\text { Türleri }\end{array}$ & Toplam \\
\hline 2000 TL ve daha Az & 147 & 20 & 63 & 14 & 9 & 5 & 6 & $264(\% 39)$ \\
$\%$ & 55,7 & 7,6 & 23,9 & 5,3 & 3,4 & 1,9 & 2,3 & 100,0 \\
2001 TL - 3500 TL & 138 & 8 & 48 & 12 & 17 & 6 & 12 & $241(\% 35,6)$ \\
$\%$ & 57,3 & 3,3 & 19,9 & 5,0 & 7,1 & 2,5 & 5,0 & 100,0 \\
3501 TL ve üzeri & 88 & 7 & 39 & 6 & 26 & 5 & 1 & $172(\% 25,4)$ \\
$\%$ & 51,2 & 4,1 & 22,7 & 3,5 & 15,1 & 2,9 &, 6 & 100,0 \\
\hline Toplam & 373 & 35 & 150 & 32 & 52 & 16 & 19 & $677(\% 100)$ \\
$\%$ & 55,1 & 5,2 & 22,1 & 4,7 & 7,7 & 2,4 & 2,8 & 100,0 \\
\hline \hline Pearson Chi-Square: 33,958 p $<0.05$ & & & & & & & &
\end{tabular}

Tablo 8'de verilen bilgiler doğrultusunda "En fazla tükettiğiniz balık türü nedir?" sorusuna verilen cevaplar bakımından gelir durumu arasında bir farklılığın olup olmadığını tespit etmek amaciyla yapılan Ki-Kare bağımsızlık testi sonucunda önemli bir farklılığın olduğu ortaya çıkmıştır $(p<0,05)$. Geliri 3501 TL ve üzeri olanların \%15,1'i çipura/levrek tüketirken, geliri 2000 TL ve daha az olanlarda bu oran $\% 3,4$ olarak belirlenmiştir.

Gelir durumuna bağlı olarak "Balık tüketim sıklığınız nedir" sorusuna katılımcıların vermiş oldukları cevapların Ki-Kare testi ile analizi Tablo 9'da verilmiştir.

Tablo 9'da verilen bilgiler doğrultusunda "Balık tüketim sıklığınız nedir?" sorusuna verilen cevaplar bakımından gelir durumu arasında bir farklılığın olup olmadığını tespit etmek amacıyla yapılan Ki-Kare bağımsızlık testi sonucunda önemli bir farklılığın olduğu ortaya çıkmıştır $(p<0,05)$. Geliri 3501 TL ve üzeri olanların \%26,7'si haftada bir balık tüketirken, Geliri 2000 TL ve daha az olanlarda bu oran \%12,5 olarak belirlenmiştir.

Gelir durumuna bağlı olarak "Aylık ortalama balık tüketiminiz kaç kilogramdır" sorusuna katılımcıların vermiş oldukları cevapların Ki-Kare testi ile analizi Tablo 10'da verilmiştir. 
Tablo 9. Balık tüketim sıklığınız nedir?

\begin{tabular}{cccccc}
\hline \hline & Haftada Bir & İki Haftada Bir & Ayda Bir & Yllda Bir & Toplam \\
\hline 2000 TL ve daha az & 33 & 72 & 111 & 48 & 264 \\
$\%$ & 12,5 & 27,3 & 42,0 & 18,2 & 100,0 \\
2001 TL - 3500 TL & 61 & 55 & 88 & 37 & 241 \\
$\%$ & 25,3 & 22,8 & 36,5 & 15,4 & 100,0 \\
3501 TL ve üzeri & 46 & 46 & 58 & 22 & 172 \\
$\%$ & 26,7 & 26,7 & 33,7 & 12,8 & 100,0 \\
\hline Toplam & 140 & 173 & 257 & 107 & 677 \\
$\%$ & 20,7 & 25,6 & 38,0 & 15,8 & 100,0 \\
\hline \hline
\end{tabular}

Tablo 10. Aylık ortalama balık tüketiminiz kaç kilogramdır?

\begin{tabular}{cccccc}
\hline \hline & $\begin{array}{c}\text { Aylık } \\
\mathbf{0 - 3 ~ K g}\end{array}$ & $\begin{array}{c}\text { Aylık } \\
\mathbf{4 - 7} \mathbf{~ K g}\end{array}$ & $\begin{array}{c}\text { Aylık } \\
\mathbf{8 - 1 1 ~ K g}\end{array}$ & $\begin{array}{c}\text { Aylık 12 Kg } \\
\text { ve üzeri }\end{array}$ & Toplam \\
& 166 & 66 & 16 & 16 & 264 \\
2000 TL ve daha az & 62,9 & 25,0 & 6,1 & 6,1 & 100,0 \\
$\%$ & 117 & 62 & 35 & 27 & 241 \\
2001 TL - 3500 TL & 48,5 & 25,7 & 14,5 & 11,2 & 100,0 \\
$\%$ & 87 & 59 & 14 & 7,0 & 172 \\
3501 TL ve üzeri & 50,6 & 34,3 & 8,1 & 55 & 100,0 \\
$\%$ & 370 & 187 & 65 & 8,1 & 677 \\
Toplam & 54,7 & 27,6 & 9,6 & & 100,0 \\
\hline
\end{tabular}

Pearson Chi-Square: $23,568 \mathrm{p}<0.05$

Tablo 10'da verilen bilgiler doğrultusunda "Aylık ortalama balık tüketiminiz kaç kilogramdır" sorusuna verilen cevaplar bakımından gelir durumu arasında bir farklılığın olup olmadığını tespit etmek amacıyla yapılan Ki-Kare bağımsızlık testi sonucunda önemli bir farklılığın olduğu ortaya çıkmıştır $(\mathrm{p}<0,05)$. Geliri $2000 \mathrm{TL}$ ve daha az olanların \%62,9'u aylık ortalama 0 ile $3 \mathrm{~kg}$ arasında balık tüketirken, geliri 2001 ile $3500 \mathrm{TL}$ arasında olanlarda bu oran \%48,5 olarak belirlenmiştir.

Gelir durumuna bağlı olarak "Erzurum'da balık fiyatları nasıl" sorusuna katılımcıların vermiş oldukları cevapların Ki-Kare testi ile analizi Tablo 11'de verilmiştir.

Tablo 11. Erzurum'da balık fiyatları nasil?

\begin{tabular}{ccccc}
\hline \hline & Pahall & Normal & Ucuz & Toplam \\
\hline 2000 TL ve daha az & 167 & 92 & 5 & 264 \\
$\%$ & 63,3 & 34,8 & 1,9 & 100,0 \\
2001 TL - 3500 TL & 146 & 82 & 13 & 241 \\
$\%$ & 60,6 & 34,0 & 5,4 & 100,0 \\
3501 TL ve üzeri & 123 & 47 & 2 & 172 \\
$\%$ & 71,5 & 27,3 & 1,2 & 100,0 \\
\hline Toplam & 436 & 221 & 20 & 677 \\
$\%$ & 64,4 & 32,6 & 3,0 & 100,0 \\
\hline \hline
\end{tabular}

Pearson Chi-Square: $11,704 \mathrm{p}<0.05$

Tablo 11'de verilen bilgiler doğrultusunda "Erzurum'da balık fiyatları nasıl" sorusuna verilen cevaplar bakımından gelir durumu arasında bir farklılığın olup olmadığını tespit etmek amaciyla yapılan Ki-Kare bağımsızlık testi sonucunda önemli bir farklılığın olduğu ortaya çıkmıştır $(p<0,05)$. Geliri 3501 TL ve üzeri olanların \%71,5'i balık fiyatlarını pahalı bulurken, geliri 2001 ile $3500 \mathrm{TL}$ arasinda olanlarda bu oran \%60,6 olarak belirlenmiştir.

Gelir durumuna bağlı olarak "Eğer kırmızı etin, tavuk etinin, balığın ve yumuşakçaların fiyatları aynı olsaydı ilk hangisini tercih ederdiniz" sorusuna katılımcıların vermiş oldukları cevapların KiKare testi ile analizi Tablo 12'de verilmiştir. 
Tablo 12. Eğer kırmızı etin, tavuk etinin, balığın ve yumuşakçaların fiyatları aynı olsaydı ilk hangisini tercih ederdiniz?

\begin{tabular}{|c|c|c|c|c|c|}
\hline & Kırmızı Et & Tavuk Eti & Balık & $\begin{array}{c}\text { Yumuşakçalar } \\
\text { (Midye..vb) }\end{array}$ & Toplam \\
\hline 2000 TL ve daha az & 197 & 25 & 32 & 10 & 264 \\
\hline$\%$ & 74,6 & 9,5 & 12,1 & 3,8 & 100,0 \\
\hline $2001 \mathrm{TL}-3500 \mathrm{TL}$ & 167 & 14 & 52 & 8 & 241 \\
\hline$\%$ & 69,3 & 5,8 & 21,6 & 3,3 & 100,0 \\
\hline 3501 TL ve üzeri & 114 & 8 & 45 & 5 & 172 \\
\hline$\%$ & 66,3 & 4,7 & 26,2 & 2,9 & 100,0 \\
\hline Toplam & 478 & 47 & 129 & 23 & 677 \\
\hline$\%$ & 70,6 & 6,9 & 19,1 & 3,4 & 100,0 \\
\hline
\end{tabular}

Pearson Chi-Square: $17,563 \mathrm{p}<0.05$

Tablo 12'de verilen bilgiler doğrultusunda "Eğer kırmızı etin, tavuk etinin, balığın ve yumuşakçaların fiyatları aynı olsaydı ilk hangisini tercih ederdiniz?" sorusuna verilen cevaplar bakımından gelir durumu arasında bir farklılığın olup olmadığını tespit etmek amacıyla yapılan KiKare bağımsızlık testi sonucunda önemli bir farklılığın olduğu ortaya çıkmıştır $(p<0,05)$. Geliri 3501 TL ve üzeri olanların \%26,2'si balığı tercih ederken, geliri 2000 TL ve daha az olanlarda bu oran $\% 12,1$ olarak belirlenmiştir.

Mesleğe bağlı olarak "Balık satın alırken en çok nelere dikkat edersiniz" sorusuna katılımcıların vermiş oldukları cevapların Ki-Kare testi ile analizi Tablo 13’te verilmiştir.

Tablo 13. Balık satın alırken en çok nelere dikkat edersiniz?

\begin{tabular}{cccccccc}
\hline \hline & Fiyatına & $\begin{array}{c}\text { Lezzetli } \\
\text { Olmasına }\end{array}$ & Tazeliğine & $\begin{array}{c}\text { Az Kılçıklı } \\
\text { Olmasına }\end{array}$ & Hepsi & Diğer & Toplam \\
\hline Öğrenci, Emekli, Ev & 35 & 3 & 54 & 12 & 58 & 4 & 166 \\
Hanımı, Geçici İşsiz & 21,1 & 1,8 & 32,5 & 7,2 & 34,9 & 2,4 & 100,0 \\
$\%$ & 43 & 27 & 139 & 18 & 61 & 9 & $297(\% 43,9)$ \\
Özel Sektör & 14,5 & 9,1 & 46,8 & 6,1 & 20,5 & 3,0 & 100,0 \\
$\%$ & 26 & 6 & 123 & 11 & 46 & 2 & $214(\% 31,6)$ \\
Kamu & 12,1 & 2,8 & 57,5 & 5,1 & 21,5 &, 9 & 100,0 \\
$\%$ & 104 & 36 & 316 & 41 & 165 & 15 & $677(\% 100)$ \\
Toplam & 15,4 & 5,3 & 46,7 & 6,1 & 24,4 & 2,2 & 100,0 \\
\hline & & & & & & &
\end{tabular}

Pearson Chi-Square: 45,235 p<0.05

Tablo 13'te verilen bilgiler doğrultusunda "Balık satın alırken en çok nelere dikkat edersiniz?" sorusuna verilen cevaplar bakımından meslek grupları arasında bir farklılı̆̆ın olup olmadığını tespit etmek amacıyla yapılan Ki-Kare bağımsızlık testi sonucunda önemli bir farklılığın olduğu ortaya çıkmıştır $(\mathrm{p}<0,05)$. Kamu sektöründe çalışanların \%57,5'i tazeliğine dikkat ederken, öğrenci, emekli, ev hanımı ve geçici işsizlerde bu oran \%32,5 olarak belirlenmiştir.

\section{TARTIŞMA ve ÖNERILER}

Bu çalışmamızda Erzurum İlinin Merkez ilçelerinde ikamet eden katılımcılara su ürünleri tüketim tercih ve alışkanlıklarına yönelik sorular sorularak verilen cevaplar istatistiki olarak değerlendirilmiştir. Erzurum'da su ürünleri tüketim davranışlarına yönelik çalışmamız neticesinde aşağıda sıralanan sonuçlar elde edilmiştir.

Çalışmamızda, Balık satın alırken en çok nelere dikkat edersiniz? Sorusuna verilen cevaplar değerlendirilmiş benzer çalışmalarla karşılaştırılmıştır. Diyarbakır ili su ürünleri tüketim alışkanlıkları üzerine yapılan araştırmaya göre tüketicilerin su ürünleri satın alırken \%26,6'ının ürünün tazeliğini, \%23,5 fiyatına, \%15.5'i de tür ve bulunabilirlik kriterlerine baktıklarını belirtmişlerdir (Odabaşı, 2016). Aynı şekilde Denizli ilinde su ürünleri tüketim alışkanlıkları üzerine bir çalışma yapılmış ve bireylerin \%82'i balık satın alırken tazeliğine dikkat ettiklerini belirtmişlerdir (Telli, 2018). Kahramanmaraş ili merkez ilçede balık tüketim alışkanlıkları üzerine yapılan çalışmaya göre katılımcıların balık satın alırken \%73'ü tazeliğine bakmaktadır (Beyazbayrak, 2014), Aynı soruya 
değişik bölgelerdeki farklı cevaplar, balık tüketim şeklini ve tercihini coğrafik koşullar ve alışkanlıkların oluşturduğu kanaatine varmamıza sebep olmuştur.

Erzurum ilinde tüketicilere Balık dışı en çok hangi su ürünlerini tüketmektesiniz? Sorusuna verilen cevaplar benzer çalışmalarla karşılaştırılmıştır verilen cevaplar Batman ve Kahramanmaraş'ta yapılan çalışmalarla benzerlik göstermiştir (Akkuş vd., 2018; Beyazbayrak, 2014). Denize kıyısının bulunmaması ayrıca geçmişten gelen yemek kültürü durumla yakından ilişkilidir. Ayrıca Balık harici su ürünlerinin yeteri kadar tanıtılmaması da önemli bir faktör olarak değerlendirilmektedir.

Çalışmamızdan çıkarılan önemli sonuçlardan biride "Balık Tüketmenizin En Önemli Sebebi Nedir" sorusuna, Yaşları 18 altı olan çocukların \%80,6'sının sağlık şeklinde vermiş oldukları cevaptır. $\mathrm{Bu}$ durum okul çağındaki bireylere balığın sağlık açısından önemi hakkında bilinçlendirmeler yapılmasının sonucu olarak görülmektedir. Balık tüketiminin teşvik edilerek arttırılması için benzer çalışmaların artarak devam etmesi sonucu da doğal olarak ortaya çıkmaktadır. Benzer şekilde Sizce balık tüketimini etkileyen faktörlerden en önemlisi nedir sorusuna verilen cevaplarda da benzer durum söz konusudur.

Çalışmamızın ilginç sonuçlarından birisi olan su ürünleri denilince aklınıza gelen ilk canlı türü hangisidir sorusuna Eğitim durumları Üniversite ve üzeri olan katılımcıların \% 92,3’ü balık derken okur-yazar olmayanların \% 43,8'nin balık şeklinde cevap vermesidir. Aynı sorunun detayına bakıldığında okur-yazar olmayan katılımcıların çeşitli su bitkilerini, yumuşakçaları ve diğer canlıları da su ürünleri olarak değerlendirdikleri görülmektedir. Bu anlamda eğitim seviyesiyle su ürünleri arasındaki bu enteresan sonucun farklı çalışmalarla değerlendirilmesi ve araştırılması gerektiğ düşünülmektedir.

Çalışmamızda sorulan "Sizce balık tüketmeli miyiz" sorusuna eğitim düzeyleri üniversite ve üzeri olan katılımciların \%97,3'ü evet derken okur-yazar olmayanlarda bu oran \%56,3 olarak ortaya çıkmıştır. Sonucun bu şekilde çıkması balık tüketiminin sağlık açısından önemi konularının eğitim aracılığı ile bireylere anlatıldığını okur-yazar olmayan bireylerin balık tüketiminin önemi hakkında bilgilendirilmesi gerektiği anlamı taşımaktadır. Özellikle ilköğretim seviyesinden verilecek eğitim gelecek adına faydalı olacaktır.

Çalışmamızın önemli sorularından biri olan "En fazla tükettiğiniz balık türü nedir" sorusu $\% 55,1$ hamsi, \%22,2 alabalık, \%7,7 çipura/levrek, \%5,2 istavrit, \%4,7 sazan, \%2,4 somon ve $\% 2,8$ diğer balık türlerini şeklinde cevaplanmıştır. Buradan çıkan sonuç yörenin ekonomik açıdan daha uygun balıkları tercih ettiği anlamını taşımaktadır. Ayrıca deniz kenarında bulunmaması, farklı türlerden balık tüketimlerine ön yargı ile yaklaşılması gibi nedenlerde tüketilen balık türünü etkilemektedir.

Çalışmamızda "Balık tüketim sıklığınız nedir" sorusuna Geliri 3501 TL ve üzeri olanların \%26,7'si haftada bir şeklinde cevap verirken, Geliri $2000 \mathrm{TL}$ ve daha az olanlarda bu oran \%12,5 olarak belirlenmiştir. Bu sonuçtan Erzurum'da balık fiyatlarının daha ekonomik seviyelere çekilmesinin tüketimi teşvik edeceği düşünülmektedir fakat Benzer şekilde "Aylık ortalama balık tüketiminiz kaç kilogramdır" sorusuna ise Geliri 2000 TL ve daha az olanların \%62,9'u aylık ortalama 0 ile $3 \mathrm{~kg}$ arasında şeklinde cevap vermiş, geliri 2001 ile 3500 TL arasında olanlar \%48,5 olarak soruyu cevaplandırmıştır. $\mathrm{Bu}$ durum gelir seviyesi daha düşük olan katılımcıların ekonomik açıdan daha uygun olan balık türlerini tercih ettiği şeklinde yorumlanmıştır. Aynı şekilde "Erzurum'da balık fiyatları nasıl" sorusuna katılımcıların çoğunlukla pahalı şeklinde verdiği cevaplarda durumu izah etmektedir. Konuyla ilgili yapılan çalışmalarda Gelir seviyesinin düşük olmasının Su ürünleri tüketimini etkilediğini ortaya koymaktadır. Ayrıca avlanma sahasına uzak olan bölgelere su ürünlerinin ulaştırılmasında transfer masrafları nedeniyle fiyat artışları olmaktadır (Çolakoğlu vd., 2006; Gözener vd., 2016). Dolayısıyla Erzurum'da tüketimi fazla olan balık türlerinin fiyatlarının makul seviyelere çekilmesinin, tatlı su yetiştiricilik sistemlerinin geliştirilerek ulaşılabilirliğinin kolaylaştırılmasının balık tüketiminin artmasına vesile olacağ kanaatine varmamıza sebep olmuştur.

Çalışmamızın yine önemli kısımlarından biri olan "Eğer kırmızı etin, tavuk etinin, balığın ve yumuşakçaların fiyatları aynı olsaydı ilk hangisini tercih ederdiniz" sorusuna Geliri 3501 TL ve üzeri olanların \%26,2'si balığ tercih ederken, geliri $2000 \mathrm{TL}$ ve daha az olanlarda bu oran \%12,1 olarak belirlenmiştir. $\mathrm{Bu}$ durum gelir seviyesi daha düşük olan katılımcıların balığın özellikle sağlık açısından faydaları hakkında yeteri kadar bilinçlendirilmediği şeklinde yorumlanmıştır.

Son olarak çalışmamızda "Balık Satın Alırken En Çok Nelere Dikkat Edersiniz?" şeklinde sormuş olduğumuz soruya Kamu sektöründe çalışanların \%57,5'i tazeliğine dikkat ederken, öğrenci, emekli, 
ev hanımı ve geçici işsizlerde bu oran \%32,5 olarak belirlenmiştir. Bu durumda yine gelir seviyesiyle ilişkilendirilerek yorumlanmıştır.

\section{SONUÇ}

Yapmış olduğumuz çalışmada Balık tüketimini etkileyen en önemli nedenlerin başında; yeme alışkanlıkları, su ürünleri hakkında bilgi sahibi olmamak, yüksek fiyat ve yıl boyu ulaşılabilirlik gibi sebepler karşımıza çıkmaktadır. Erzurum yaklaşık 2 bin metre rakım da bulunması en yakın deniz sahiline (Karadeniz) $320 \mathrm{~km}$ mesafede olması sebebiyle su ürünlerine ulaşılabilirliği zor olan bir şehirdir. Bu durum balık tüketimini negatif anlamda etkilemektedir. Ayrıca yaptığımız çalışmada ekonomik sebeplerinde Erzurum'da balık tüketimini önemli bir şekilde etkilediği sonucunu ortaya koymuştur. Ülkemizdeki kişi başı balık tüketimi hem çok düşüktür $(5,5 \mathrm{~kg} / \mathrm{kişi} \mathrm{civarı)} \mathrm{hem} \mathrm{de}$ tüketimin önemli bir kısmını tek bir tür (Karadeniz hamsisi) oluşturmaktadır. Dolayısıyla daha sağlıklı bir toplum oluşturmak için kişi başına balık tüketim miktarının artırılmasının yanı sıra tek türe bağımlı olan üretim/tüketim dengesine mutlaka diğer türler de dahil edilmelidir. Ayrıca balığın sağlık açısından öneminin anlatılmasının tüketime olumlu yönde etki ettiği gerçeğinden hareketle bölgede su ürünleri eğitim faaliyetlerinin arttırılması kanaatine varılmıştır. Artan Dünya nüfusu ve azalan gıda kaynakları da dikkate alındığı taktirde geleceğin gıda maddesi olmaya aday olan su ürünleri şimdiden özendirilerek gelecek nesillere aşılanmalı, gerek ulaşılabilirlik gerekse uygun fiyatlarla özendirilmeli ve Dünya ortalamasının çok altında olan su ürünleri tüketimimiz artırılmalıdır. Yapmış olduğumuz bu çalışma mevcut durum analizi olmasının ötesinde geleceğe dair plan ve programlara da 1şı tutarak arzu edilen seviyeye ulaşabilme adına önemli bir veridir.

Teşekkür: $\mathrm{Bu}$ çalışma, Atatürk Üniversitesi Fen Bilimleri Enstitüsü Su Ürünleri Mühendisliği Anabilim Dalında Yüksek Lisansını tamamlayan Yaşar KARAKULAK'ın Yüksek Lisans tezinden özetlenmiştir.

\section{KAYNAKLAR}

Akkuş, S. (2018). Batman İli balık tüketim alışkanlığının belirlenmesi. Munzur Üniversitesi Fen Bilimleri Enstitüsü Yüksek Lisans Tezi, Tunceli.

Arslan, G. (2019). Determination of fish consuming habits of vocational school students from different families. Marine Science and Technology Bulletin, 8(2), 40-45.

Baysal, A. (2004). Beslenme. 10. Baskı, Hatipoğlu Yayınevi, Beşevler-Ankara.

Beyazbayrak, Z. (2014). Kahramanmaraş İli Merkez İlçede Balık Tüketim Alışkanlıkları. Kahramanmaraş Sütçü İmam Üniversitesi, Fen Bilimleri Enstitüsü. Yüksek Lisans Tezi, Kahramanmaraş.

Brown A. (2000). Understanding food fish and shellfish. Wadsworth/Thomson Learning, USA, 299-318s.

Çolakloğlu F.A., İşmen, A., Özen, O., Çakır, F., Yığın, C., \& Ormancı, H.B. (2006). Çanakkale İli’ndeki su ürünleri tüketim davranışlarının değerlendirilmesi. Ege University Journal of Fisheries and Aquatic Sciences, 23(1/3), 387-392.

Erkan, N. (2013). Türkiye'de tüketilen su ürünlerinin omega-3 yağ asidi profilinin değerlendirilmesi. Journal of Fisheries Sciences, 7(2), 194-208.

FAO (2012). The State of World Fisheries and Aquaculture, Food and Agriculture Organization of The United Nations, Rome.

Gorga, C. (1998). Quality assurance of seafood. An avi Book Published by Van Nostrand Reinhold, New York.

Gözener,B., Sayılı, M., \& Antar, S. (2016). Ordu İli Fatsa İlçesi’nde hanelerin balık tüketim alışkanlıklarının tespiti. Gaziosmanpaşa Bilimsel Araştırma Dergisi, 12, 31-43.

Hisar, ŞA. (2002). Modifiye atmosferde ambalajlamanın gökkuşağı alabalı̆̆ (Oncorhynchus mykiss) filetolarının fiziksel, kimyasal ve mikrobiyolojik özelliklerine etkisi. Atatürk Üniversitesi Fen Bilimleri Enstitüsü, Doktora Tezi, Erzurum.

Karabulut, H.A., \& Yandı. İ. (2006). Su ürünlerindeki n-3 yağ asitlerinin önemi ve sağllk üzerine etkisi. Ege Üniversitesi Su Ürünleri Dergisi, 23(1/3), 339-342

Maskan, M. (2005). Omega oils; sources, benefits and their use in enrichment of food materials. Gida Kongresi 2005. Ege Üniversitesi Mühendislik Fakültesi Gıda Mühendisliği Bölümü. 41-44.

Odabaşı, Y. (2016). Su ürünleri tüketim alışkanlıkları üzerine bir araştırma: Diyarbakır İli örneği. Ordu Üniversitesi Fen Bilimleri Enstitüsü, Yüksek Lisans Tezi, Ordu.

Pigott, G.M., \& Tucker, B.W. (1990). Seafood effects of technology on nutrition. Marcel Dekker, New York.

Telli, Ö. (2018). Denizli İli su ürünleri tüketim alışkanlıkları üzerine bir anket çalışması. Süleyman Demirel Üniversitesi, Fen Bilimleri Enstitüsü, Yüksek Lisans Tezi, Isparta.

TUIK (2014). Su Ürünleri İstatistikleri, Türkiye İstatistik Kurumu, Ankara, Türkiye İstatistik Kurumu Matbaası. 
Turan, H., Kaya, Y., \& Sönmez, G. (2006). Balık etinin besin değeri ve insan sağlığındaki yeri. Ege Üniversitesi Su Ürünleri Dergisi, 23(1/3), 505- 508. 